\title{
Experiment and Electro-Thermo-Chemical Modeling on Rapid Resistive Discharge of Large-Capacity Lithium Ion Battery
}

\author{
Chil-Hoon Doh ${ }^{1,3 *}$, Yoon-Cheol Ha ${ }^{1}$, Seung-Wook Eom ${ }^{1,3}$, Jihyun $\mathrm{Yu}^{1}$, Seon-Hwa Choe ${ }^{1,4}$, \\ Seog-Whan $\mathrm{Kim}^{2}$, and Jae-Won Choi ${ }^{1}$ \\ ${ }^{I}$ Next-generation Battery Research Center, Korea Electrotechnology Research Institute(KERI) \\ ${ }^{2}$ Superconductor Research Center, KERI \\ ${ }^{3}$ KERI Campus, Korea University of Science and Technology, Changwon, Gyeongnam 51543, Korea \\ ${ }^{4}$ Eurocell Co., Ltd., Osan, Gyeonggi, 18103, Korea
}

\begin{abstract}
Heat generation and temperature of a battery is usually presented by an equation of current. This means that we need to adopt time domain calculation to obtain thermal characteristics of the battery. To avoid the complicated

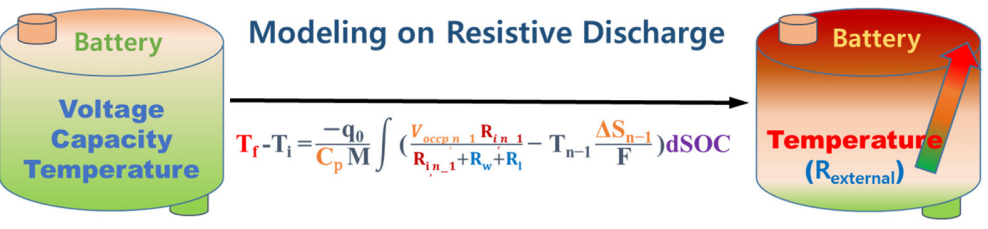
calculations using time domain, 'state of charge (SOC)' can be used as an independent variable. A SOC based calculation method is elucidated through the comparison between the calculated results and experimental results together. Experiments are carried for rapid resistive discharge of a large-capacitive lithium secondary battery to evaluate variations of cell potential, current and temperature. Calculations are performed based on open-circuit cell potential (SOC,T), internal resistance (SOC,T) and entropy (SOC) with specific heat capacity.
\end{abstract}

Keywords : Lithium Ion Battery, Resistive Discharge, External Resistance, Heat Generation, Temperature Estimation, Thermal Modeling

Received : 1 July 2021, Accepted: 15 October 2021

\section{Introduction}

The energy density of the lithium secondary battery is reaching $\sim 300 \mathrm{Wh} \mathrm{kg}^{-1}$ to be $\sim 8$ times of leadacid battery. The charged lithium secondary battery contains the solidified oxygen and the flammable organic electrolyte. Therefore, a worth case may cause an ignition [1-10]. In order to prevent thermal runaway, it is necessary to understand thermo-electro-chemical characteristics. Which is important for the operation of a large-capacity battery system constructed through series and parallel connections. The resistive discharge could be counted as a case of

*E-mail address: chdoh@keri.re.kr, chdoh@ust.ac.kr DOI: https://doi.org/10.33961/jecst.2021.00661

This is an open-access article distributed under the terms of the Creative Commons Attribution Non-Commercial License (http://creativecommons.org/licenses/by-nc/4.0) Attribution Non-Commercial License (http://creativecommons.org/licenses/by-nc/4.0)
which permits unrestricted non-commercial use, distribution, and reproduction in any which permits unrestricted non-commercial use, distri
medium, provided the original work is properly cited. external short circuit situation of battery. Sudden resistive discharge resulted inevitably heat generation to increase temperature of battery. Generated heat might be led to cell degradation, firing and explosion.

The resistive discharge of pouch type lithium ion battery ( $15 \mathrm{Ah} /$ cell) was studied to get temperature increase to $386 \mathrm{~K}$ with the external resistance of $0.562 \mathrm{~m} \Omega$ [8]. The resistive discharge of 18650 type lithium ion battery ( $2 \mathrm{Ah} / \mathrm{cell}$ ) was also studied through experiment and thermal modeling [11] Pouch battery (10 Ah/cell) was experimentally studied in details by Kriston [12]. The resistive discharge behavior of lithium ion batteries using experiment and multi-physics modeling was also studied by Rheinfeld [13,14].

To understand the resistive discharge process, the relationship between current, voltage, and temperature could be summarized as follows. The equivalent circuit for explaining the resistive discharge of the 


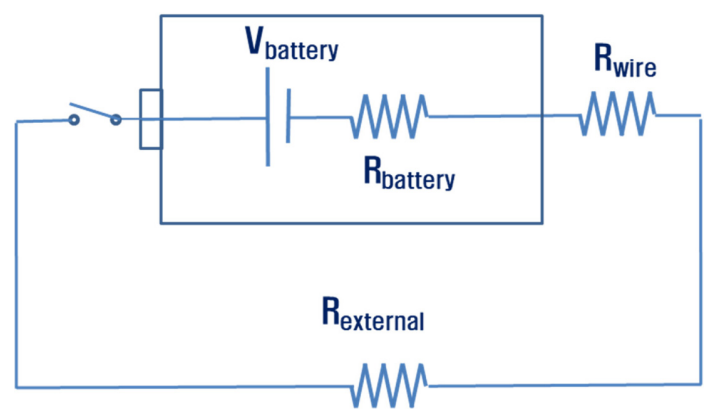

Fig. 1. Equivalent circuit for resistive discharge of battery. $\mathrm{V}_{\text {battery }}$ : cell potential of battery, $\mathrm{R}_{\text {battery }}$ : internal resistance of battery, $R_{\text {wire }}$ : wiring resistance of resistive discharge and $\mathrm{R}_{\text {external }}$ : external resistance of wiring

battery could be composed of the connection of cell potential, resistance of cell and resistance of external circuit. It would be presented as Fig. 1. The relationship between heat generation power and heat generation quantity of battery $[10,15]$ is Eq. 1 and Eq. 2 . SOC (state of charge) is a function of current and time as in Eq. 3. When SOC was changed at regular intervals, $\triangle \mathrm{SOC}$ would be a constant, and the relationship between time and current for $\triangle \mathrm{SOC}$ would be the relationship between Eqs. 4 and 5.

$$
\begin{aligned}
& \begin{aligned}
& \mathrm{Q}_{\text {total }}=\mathrm{Q}_{\text {irr }}+\mathrm{Q}_{\text {rev }}^{\cdot}=\mathrm{I}\left(\mathrm{V}_{\text {occp }}-\mathrm{V}_{\text {cccp }}\right)-\mathrm{IT}\left(\frac{\partial \mathrm{V}_{\text {occp }}}{\partial \mathrm{T}}\right) \\
&=\mathrm{I}^{2} \mathrm{R}_{\mathrm{i}}-\frac{\mathrm{IT} \Delta \mathrm{S}}{\mathrm{F}} \\
& \mathrm{Q}_{\text {total }}=\int\left(\mathrm{I}^{2} \mathrm{R}_{\mathrm{i}}-\frac{\mathrm{IT} \Delta \mathrm{S}}{\mathrm{F}}\right) \mathrm{dt} \\
& \mathrm{SOC}=\frac{\mathrm{q}_{0}-\mathrm{q}}{\mathrm{q}_{0}}=1-\frac{\mathrm{It}}{\mathrm{q}_{0}} \\
& \mathrm{dt}=-\mathrm{q}_{0} \Delta \operatorname{SOC} \mathrm{d}(1 / \mathrm{I}) \\
& \mathrm{t}=-\mathrm{q}_{0} \Delta \operatorname{SOC} \int \mathrm{d}(1 / \mathrm{I})
\end{aligned}
\end{aligned}
$$

where,

$\mathrm{Q}_{\text {total }}$ : heating power of battery

$\mathrm{Q}_{\mathrm{irr}}$ : heating power of battery by irreversible heating

$\mathrm{Q}_{\text {rev }}$ : heating power of battery by reversible heating/cooling

$\mathrm{Q}_{\text {total }}$ : heat generation of battery

I: current (A), discharge (+), charge (-)

$\mathrm{V}_{\text {occp }}$ : open-circuit cell potential $(\mathrm{V})$

$\mathrm{V}_{\text {cccp}}$ : closed-circuit cell potential (V)

$\mathrm{T}$ : temperature of battery $(\mathrm{K})$

$\mathrm{R}_{\mathrm{i}}$ : internal resistance of battery $(\mathrm{ohm}, \Omega)$
$\Delta \mathrm{S}$ : specific entropy of battery $(\mathrm{J} / \mathrm{mol} \cdot \mathrm{K}$ or $\mathrm{Wh} / \mathrm{mol} \cdot \mathrm{K})$

$\mathrm{F}$ : Faraday's constant $(\mathrm{C} / \mathrm{mol}, \mathrm{Ah} / \mathrm{mol})$

$\mathrm{t}$ : time of resistive discharge

$\mathrm{q}_{0}$ : capacity of battery $(\mathrm{Ah}, 3600$ coulomb $(\mathrm{A} \cdot \mathrm{sec}))$

SOC: state of charge (dimensionless)

$\Delta$ SOC: SOC interval for iterative calculation

The current is the difference between the open-circuit cell potential $\left(\mathrm{V}_{\text {occp }}\right)$ and the closed-circuit cell potential $\left(\mathrm{V}_{\text {cccp }}\right)$ with respect to the internal resistance $\left(\mathrm{R}_{\mathrm{i}}\right)$ of battery as shown as Eq. 6. The heat generation of battery would be expressed as a relationship directly related to $\mathrm{C}$-rate in the case of a constant current by Eq. 7, and in the case of a variable current, Eq. 8. $V_{\text {occp }}, R_{i}, \Delta S, C_{p}$, and $T$ were variables, which were function relationships of SOC, temperature, current, and resistance as shown in Eq. 9. Therefore, evaluation of these functional relationships for the cell is necessary. $V_{\text {occp }}, R_{i}, \Delta S$, and T could be calculated for a small SOC variation, so iteration calculation could be performed by applying the result of the (n-1)th step to the calculation of the nth step. The total resistance was the sum of the internal resistance of the battery and the external resistance. When Eq. 10 was connected to Eq. 6 and the equivalent circuit in Fig. 1, it was related to Eq. 11. $\mathrm{C}_{\mathrm{p}}$ fluctuated somewhat depending on SOC, but it was sufficient to see it as a constant. Based on Eq. 8, it is possible to iteratively calculate the change of current, cell potential and temperature according to the change of time or SOC by linking Eq. 5 and Eq. 11. Applying the initial conditions of battery capacity, initial temperature, initial SOC, final SOC, external resistance, and $\mathrm{C}_{\mathrm{p}}$, iterative calculation could be performed by concurrently linking the functional relationship of $\mathrm{V}_{\text {occp }}, \mathrm{R}_{\mathrm{i}}$, and $\Delta \mathrm{S}$ according to temperature and SOC.

$$
\begin{aligned}
& \mathrm{I}=\frac{\mathrm{V}_{\mathrm{occp}}-\mathrm{V}_{\mathrm{cccp}}}{\mathrm{R}_{\mathrm{i}}}=\mathrm{Cq}_{0} \\
& \mathrm{Q}_{\text {total,bat }}=-\mathrm{q}_{0} \int\left(\mathrm{C}_{0} \mathrm{R}_{\mathrm{i}, \mathrm{n}-1}-\mathrm{T}_{\mathrm{n}-1} \frac{\Delta \mathrm{S}_{\mathrm{n}-1}}{\mathrm{~F}}\right) \mathrm{dSOC} \\
& =\mathrm{C}_{\mathrm{p}} \mathrm{M}\left(\mathrm{T}_{\mathrm{f}}-\mathrm{T}_{\mathrm{i}}\right) \\
& \mathrm{Q}_{\text {total, bat }}=-\mathrm{q}_{0} \int\left(\frac{\mathrm{V}_{\text {occp } \mathrm{n}-1} \mathrm{R}_{\mathrm{i}, \mathrm{n}-1}}{\mathrm{R}_{\mathrm{i}, \mathrm{n}-1}+\mathrm{R}_{\mathrm{w}}+\mathrm{R}_{1}}-\mathrm{T}_{\mathrm{n}-1} \frac{\Delta \mathrm{S}_{\mathrm{n}-1}}{\mathrm{~F}}\right) \mathrm{dSOC} \\
& =\mathrm{C}_{\mathrm{p}} \mathrm{M}\left(\mathrm{T}_{\mathrm{f}}-\mathrm{T}_{\mathrm{i}}\right) \\
& \mathrm{V}_{\text {cccp }}=\mathrm{f}(\mathrm{SOC}, \mathrm{T}, \mathrm{I}, \mathrm{R}) ; \mathrm{V}_{\text {occp }}=\mathrm{f}(\mathrm{SOC}, \mathrm{T}) \text {; } \\
& \Delta \mathrm{S}=\mathrm{f}(\mathrm{SOC}) ; \mathrm{R}_{\mathrm{i}}=\mathrm{f}(\mathrm{SOC}, \mathrm{T})
\end{aligned}
$$




$$
\begin{aligned}
& \mathrm{R}_{\text {total }}=\mathrm{R}_{\text {internal }}+\mathrm{R}_{\text {external }}=\mathrm{R}_{\mathrm{i}}+\left(\mathrm{R}_{\mathrm{w}}+\mathrm{R}_{\mathrm{l}}\right) \\
& \mathrm{I}=\frac{\mathrm{V}_{\text {occp }}-\mathrm{V}_{\text {cccp }}}{\mathrm{R}_{\mathrm{i}}}=\frac{\mathrm{V}_{\text {occp }}}{\mathrm{R}_{\mathrm{i}}+\mathrm{R}_{\mathrm{w}}+\mathrm{R}_{1}}=\frac{\mathrm{V}_{\text {cccp }}}{\mathrm{R}_{1}+\mathrm{R}_{\mathrm{w}}}
\end{aligned}
$$

Where,

Subscript n-1 and n: the initial state and the calculated state of iterative calculation

Subscript i, w and l: internal, wiring and load (external)

$\mathrm{T}_{\mathrm{n}-1}$ : initial temperature before each iteration $\operatorname{step}(\mathrm{K})$

$\mathrm{T}_{\mathrm{n}}$ : final temperature after each iteration step $(\mathrm{K})$

$\mathrm{T}$ : Average temperature of $T_{n}$ and $T_{n-1}$ or to be $T_{n-1}$ as the narrow dividing

$\mathrm{T}_{\mathrm{i}}$ initial temperature before the resistive discharge $(\mathrm{K})$

$\mathrm{T}_{\mathrm{f}}$ : final temperature after the resistive discharge $(\mathrm{K})$

M: mass of battery (g)

$\mathrm{C}_{\mathrm{p}}$ : specific heat capacity of battery $(\mathrm{J} / \mathrm{g} \cdot \mathrm{K}$ or $\mathrm{Wh} / \mathrm{g} \cdot \mathrm{K})$

$\mathrm{C}$ : C-rate $\left(\mathrm{h}^{-1}\right)$, discharge $(+)$, charge $(-)$

$\mathrm{R}_{\mathrm{w}}$ : resistance of wiring $(\Omega)$

$\mathrm{R}_{\mathrm{l}}$ : resistance of external load $(\Omega)$

$\mathrm{R}_{\text {total }}$ : resistance of battery and load $(\Omega)$

$\mathrm{R}_{\text {internal }}+\mathrm{R}_{\text {external }}\left(\mathrm{R}_{\text {wire }}+\mathrm{R}_{\text {load }}\right)$

dSOC: differential SOC.

In this study, the rapid resistive discharge was tested to obtain relevant thermochemical information, and the obtained thermochemical characteristics were simulated by applying thermo-electrochemical modeling to analyze the results to confirm the validity of the model and to provide some example of extended application.

\section{Experimental}

A graphite/NCM lithium ion battery (graphite/Li(NiCo-Mn) $\mathrm{O}_{2}$; ca. $\left.2 \mathrm{~kg} ; 170(\mathrm{l}) \times 45(\mathrm{w}) \times 125(\mathrm{~h}) \mathrm{mm}^{3}\right)$ was used herein prepared for $\mathrm{R} \& \mathrm{D}$.

\subsection{Charged batteries}

Batteries for the resistive discharge were checked the behavior of charge-discharge after then fully charged again. Batteries were charged to using the galvanostatic condition of the current of $47 \mathrm{~A} /$ cell to the voltage of $4.15 \mathrm{~V}$ and were continued with the potentiostatic condition of cell potential of $4.15 \mathrm{~V}$ until the current of $4.7 \mathrm{~A}$. The discharge was performed using the galvanostatic condition of the current of $47 \mathrm{~A} /$ cell to the voltage of $2.70 \mathrm{~V}$. A machine of Model PSC120(120 V, 100 A, PNESOLUTION Co., Ltd.) was used.

\subsection{Resistive discharge}

The resistive discharge was performed using an equipment (JM System Co., Ltd., Korea) built in 2017 at KERI. This equipment employed an electronic switching system to get the switching speed less than $1 \mu \mathrm{s}$. The external resistance for rapid resistive discharge was composed as variable 8-step type as $0 \mathrm{~m} \Omega, 2 \mathrm{~m} \Omega, 5 \mathrm{~m} \Omega, 10 \mathrm{~m} \Omega, 15 \mathrm{~m} \Omega, 20 \mathrm{~m} \Omega$, $25 \mathrm{~m} \Omega$, and $80 \mathrm{~m} \Omega$. The accuracy of resistance was $+0 \%$ and $-10 \%$. The maximum input voltage was $500 \mathrm{~V}$. The voltage range was composed as 5 ranges to be $5 \mathrm{~V}, 50 \mathrm{~V}, 100 \mathrm{~V}, 200 \mathrm{~V}$, and $500 \mathrm{~V}$ with the accuracy of voltage of $\pm 1 \%$. The maximum current of the resistive discharge was 50,000 A. The current range was composed as 4 ranges to be $1,000 \mathrm{~A}$, $5,000 \mathrm{~A}, 10,000 \mathrm{~A}$, and 50,000 A to be the accuracy of current of $\pm 0.5 \%$. The measurable temperature range was from room temperature to $1,273 \mathrm{~K}$ with the thermocouple of $\mathrm{K}$ type $(\mathrm{Ni}-\mathrm{Cr} / \mathrm{Ni}-\mathrm{Al})$. Accuracy of temperature was $\pm 0.5 \mathrm{~K}$. The maximum data acquisition rate was $200,000 / \mathrm{s}$. The data acquisition used a time interval of $0.001 \mathrm{sec}$ was used. The construction scheme of the equipment was shown as Fig. 2.

DAS for temperature measurement was configured by KEYSIGHT Technologies' equipment and programs. The data logger with LXI Data Acquisition (34972A), the switch unit of Multiflex (34901A), and the control software of Benchvue were used. In the measurement, the DAS data acquisition used a time interval of $0.001 \mathrm{sec}$ for the external resistance of $0.91 \mathrm{~m} \Omega$ and $2.91 \mathrm{~m} \Omega$, and $0.5 \mathrm{sec}$ for $5.91 \mathrm{~m} \Omega$. Fully charged batteries were subjected to the resistive discharge tests. A thermocouple of $\mathrm{J}$ type $(\mathrm{Fe} / \mathrm{Cu}-\mathrm{Ni}$ ) was used to measure the temperature variation of battery as attached to the center of $\mathrm{x}-\mathrm{Z}$ plane of battery surface assigned as center position $(0.5,0,0.5)$. For the coordination of thermocouple, the length-direction was from the positive terminal side to the negative terminal side in $(+) \mathrm{x}$ direction, the width-direction was symmetrical to be the $y$ direction, and the height-direction was from the far side of the electrode terminal to the electrode terminal in the $(+) \mathrm{z}$ direction. The resistance of wiring was varied slightly for each test turn because of reconnection as test by test. In this experiment, in order to reduce the fastening resistance of the terminal connection of battery, laser welding was performed on the positive and the negative electrode terminals 
(a)

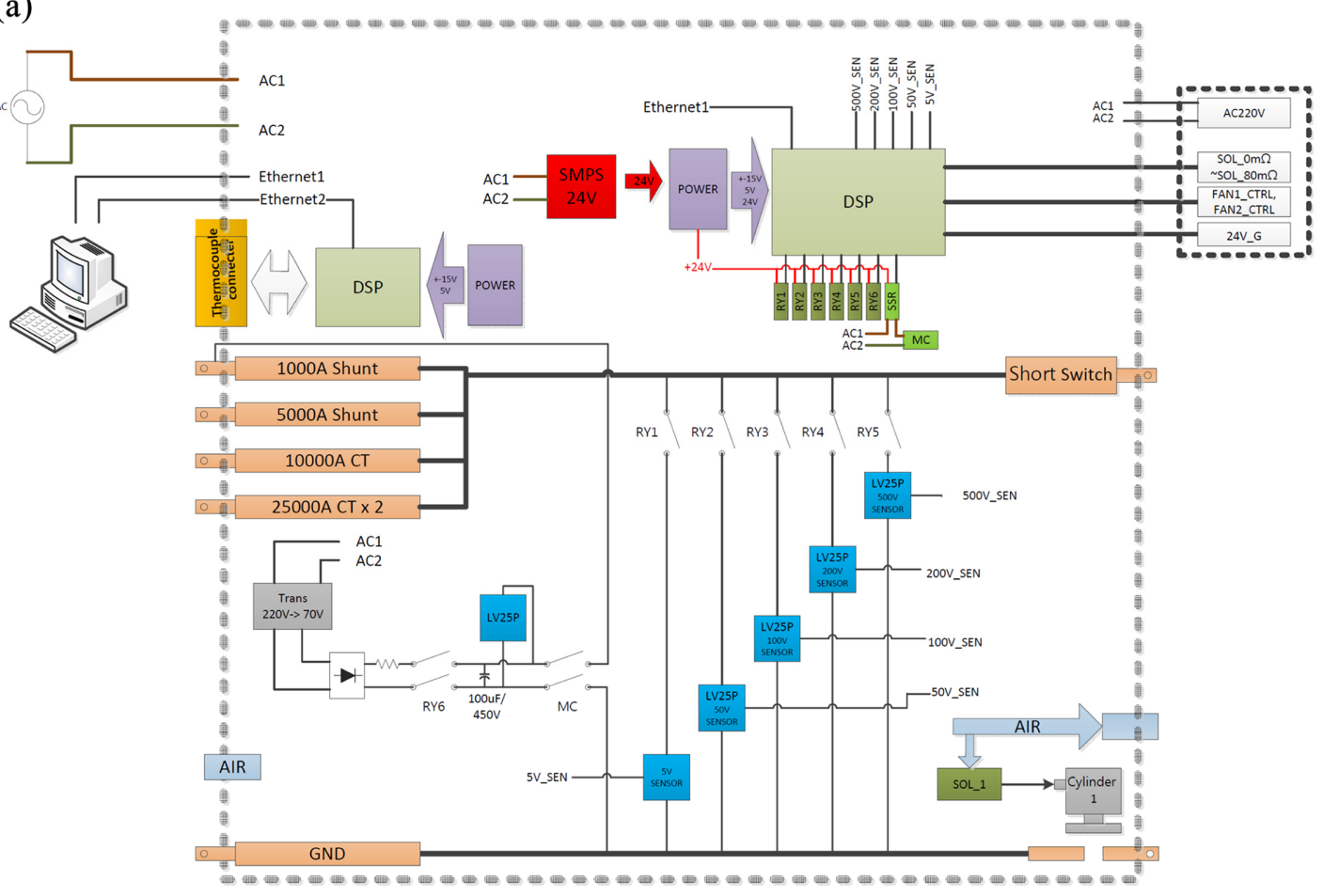

(b)

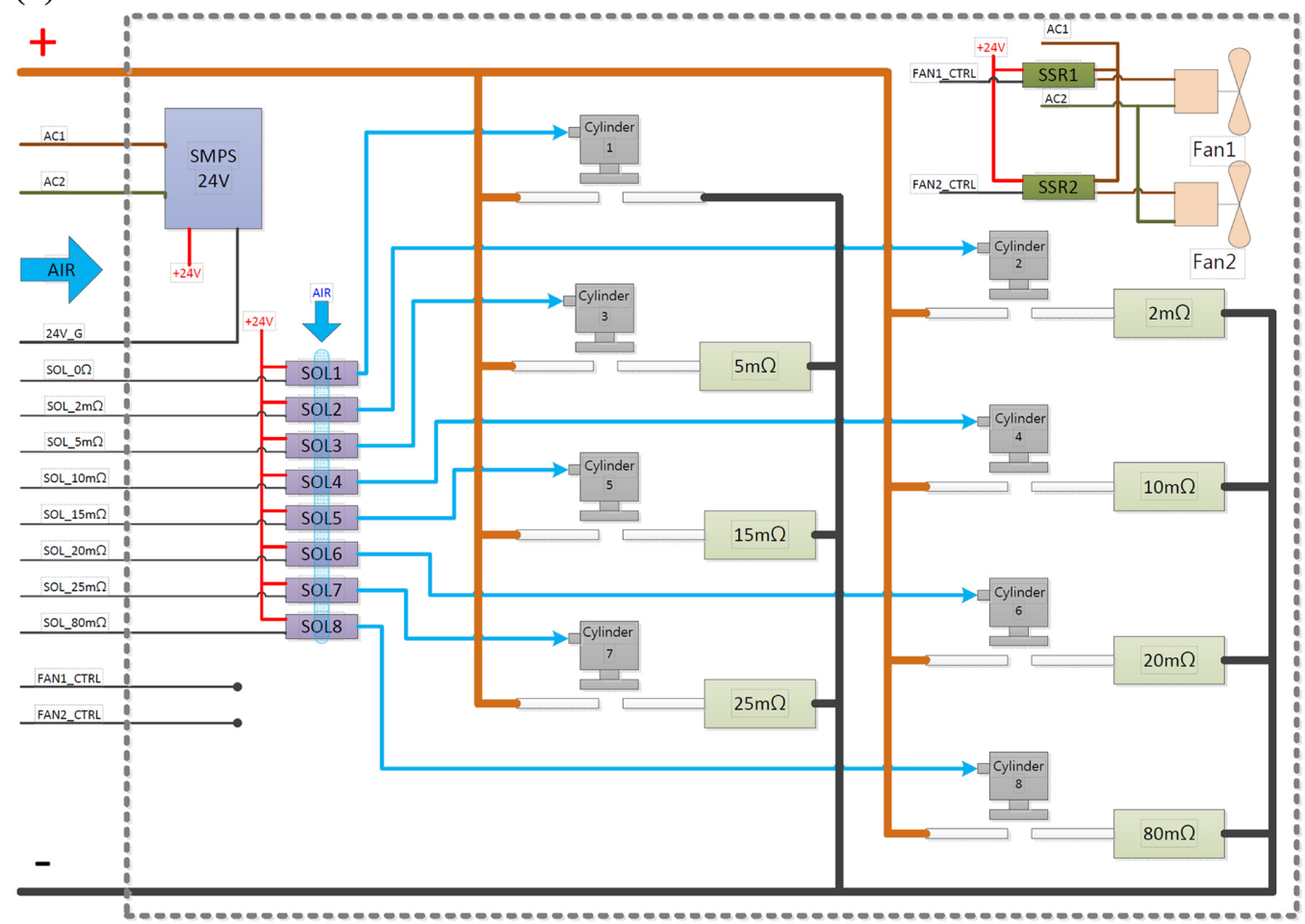

Fig. 2. Apparatus for resistive discharge of batteries. (a) configuration and (b) resister configuration. 
using a thick Ni metal plate. The circuit of a resistive discharge test was tightly connected to the laserwelded Ni metal plate of battery. The wiring resistance including extended Ni-plate terminals was 0.91 $\mathrm{m} \Omega$. On the other hand, in the case of direct connecting using a bolt/nut without laser-welded Ni-tap, the wiring resistance was $2.25 \mathrm{~m} \Omega$.

\subsection{Modeling on resistive discharge}

For the functional relationship of $\mathrm{C}_{\mathrm{p}}, \Delta \mathrm{S}, \mathrm{V}_{\text {occp }}$, and $\mathrm{R}_{\mathrm{i}}$ used in modeling, published results [16] of an iterative electro-thermo-chemical modeling (IETCM) calculation program was used. The fractionation number of SOC was used as 1,000 dividing.

As shown in the introduction, the general expression of non-galvanostatic conditions was applied to simulate the resistive discharge. The resistive discharge is a sudden discharge reaction, which is close to a quasi-adiabatic state because of the difficulty of the heat dissipation.

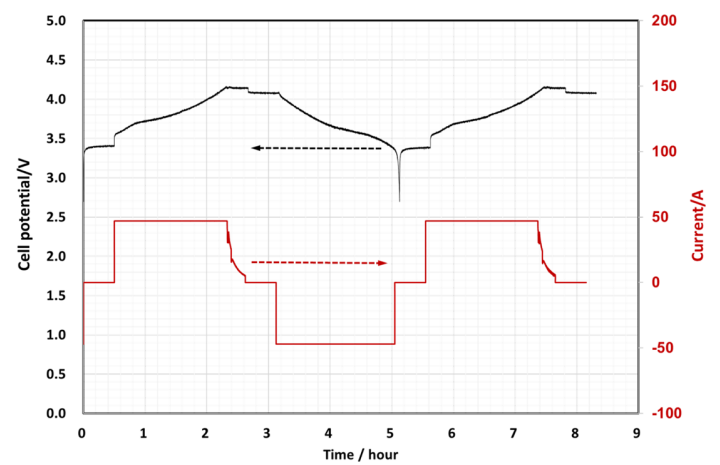

Fig. 3. Typical charge-discharge profile for test battery.

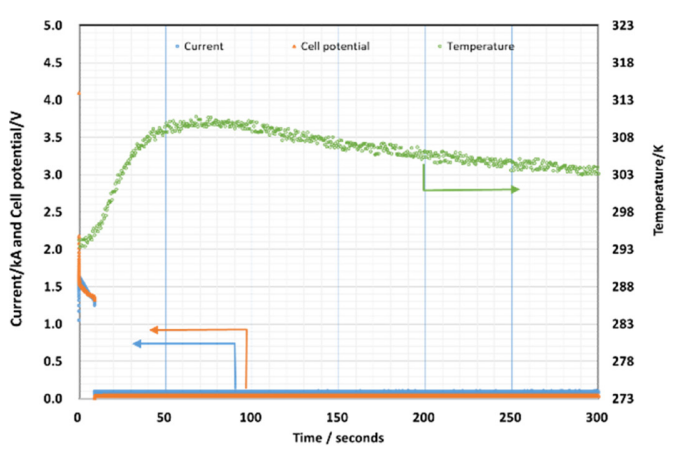

(a)

\section{Results and Discussion}

\subsection{Charged batteries}

Typical charge-discharge profile was depicted as Fig. 3. The battery used for each resistive discharge test was a graphite/Li(Ni-Co-Mn) $\mathrm{O}_{2}$ lithium secondary battery, which weighed as $2 \mathrm{~kg}$, and had a capacity of about $90 \mathrm{Ah}$ when charging the cell potential to $4.15 \mathrm{~V}$. The charge and discharge capacity of the battery used for each resistive discharge test were shown as Table 1.

\subsection{Resistive discharge with along total external resistance of $0.91 \mathrm{~m} \Omega$}

The results of the resistive discharge as the variations of cell potential, current, and temperature under the total external resistance of $0.91 \mathrm{~m} \Omega$ composed by the additional external resistive load of $0 \mathrm{~m} \Omega$ and the line resistance of $0.91 \mathrm{~m} \Omega$ was shown at Fig. 4 .

The cell potential before the resistive discharge of the fully charged battery was $4.09 \mathrm{~V}$, and the temperature was $294 \mathrm{~K}$. The maximum resistive discharge current was 1,634 A, which appeared at 0.174 seconds, and the cell potential was $1.57 \mathrm{~V}$. Over time, the current gradually decreased, and after 9 seconds, the current

Table 1. Charge-discharge capacities of batteries to be used for resistive discharge

\begin{tabular}{cccc}
\hline \hline $\begin{array}{c}\text { Pre-measured } \\
\text { external resistance }(\mathrm{m} \Omega)\end{array}$ & $\begin{array}{c}1^{\text {st }} \\
\text { charge }\end{array}$ & $\begin{array}{c}1^{\text {st }} \\
\text { discharge }\end{array}$ & $\begin{array}{c}2^{\text {nd }} \\
\text { charge }\end{array}$ \\
\hline 0.91 & 90.76 & 91.82 & 92.04 \\
2.91 & 90.42 & 90.46 & 89.98 \\
5.91 & 90.64 & 91.57 & 91.65 \\
\hline
\end{tabular}

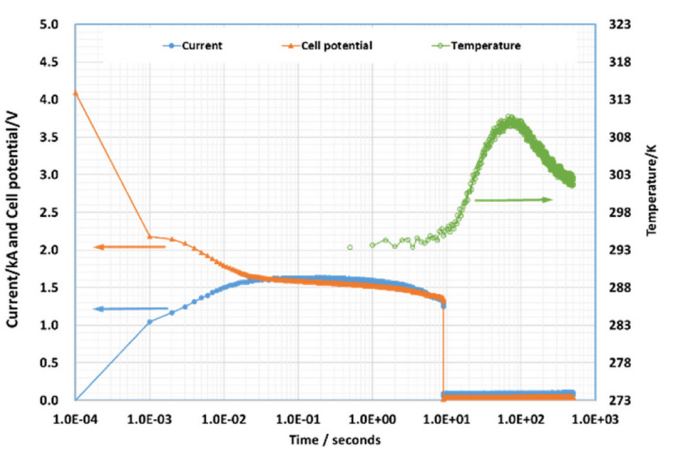

(b)

Fig. 4. Cell potential, current and temperature variations during the resistive discharge with external resistance of $0.91 \mathrm{~m} \Omega$. (a) normal time scale and (b) logarithmic time scale. 
Table 2. Variations of cell potential, current and temperature during resistive discharge with the initial external resistance of $0.91 \mathrm{~m} \Omega$

\begin{tabular}{|c|c|c|c|c|c|c|c|}
\hline \multirow{2}{*}{$\begin{array}{l}\text { Time } \\
(\mathrm{sec})\end{array}$} & \multirow{2}{*}{$\begin{array}{l}\text { Cell potential } \\
\text { (V) }\end{array}$} & \multirow{2}{*}{$\begin{array}{l}\text { Current } \\
\text { (A) }\end{array}$} & \multicolumn{5}{|c|}{ Temperature of position (K) } \\
\hline & & & Center & $(0.174,0,0.778)$ & $(0.826,0,0.778)$ & $(0.162,0,0.222)$ & $(0.838,0,0.222)$ \\
\hline 0 & 4.09 & 0 & 294.0 & 291.3 & 292.0 & 293.5 & 294.5 \\
\hline 0.174 & 1.57 & 1,634 & - & - & - & - & - \\
\hline 0.5 & 1.54 & 1,609 & 293.3 & 291.8 & 291.6 & 294.1 & 294.6 \\
\hline 9.00 & 1.28 & 1,165 & 294.9 & 292.1 & 291.0 & 294.9 & 294.8 \\
\hline 9.01 & $\sim 0$ & n.a. & - & - & - & - & - \\
\hline 9.5 & $\sim 0$ & n.a. & 295.5 & 291.0 & 291.6 & 294.6 & 294.9 \\
\hline 46 & $\sim 0$ & n.a. & 308.6 & 292.4 & 291.9 & 303.3 & 299.6 \\
\hline 65 & $\sim 0$ & n.a. & 310.1 & 291.0 & 292.4 & 305.2 & 300.6 \\
\hline 68 & $\sim 0$ & n.a. & 310.8 & 291.0 & 292.3 & 303.8 & 301.7 \\
\hline 128 & $\sim 0$ & n.a. & 307.6 & 291.4 & 291.4 & 305.9 & 303.0 \\
\hline 185 & $\sim 0$ & n.a. & 305.8 & 291.4 & 290.8 & 303.9 & 304.2 \\
\hline
\end{tabular}

*maximum values were marked as bold character

showed 1,250 A, and suddenly the current decreased to $0 \mathrm{~A}$ and the voltage could not be measured.

This sudden failure was the result of disconnection of resistive discharge circuit due to the operation of a current limiting device. At this time, the temperature of center position of the vertical $\mathrm{x}-\mathrm{z}$ surface $(0.5,0,0.5)$ was about $295 \mathrm{~K}$. The maximum temperature was reached to $310.8 \mathrm{~K}$ at 68 seconds after the operation of current limiter.

The position $(0.174,0,0.778$, adjacent to the positive terminal) and the position $(0.826,0,0.778$, adjacent to the negative terminal) did not show a significant temperature variation before and after the resistive dis- charge. The temperature increase of the position $(0.162,0,0.222$, far from the positive terminal $)$ and the position $(0.838,0,0.222$, far from the negative terminal) were insensitive compared to center position. The variations of cell potential, current and temperature during the resistive discharge were presented as normal time scale (Fig. 4a) and logarithmic time scale (Fig. 4b), and summarized as Table 2. The maximum values of current and temperature were marked as bold character. The maximum current was measured as $1.634 \mathrm{kA}$ at the time of 0.174 seconds to be the first acquired data. The maximum temperature of center position was $310.8 \mathrm{~K}$. Time delay between the

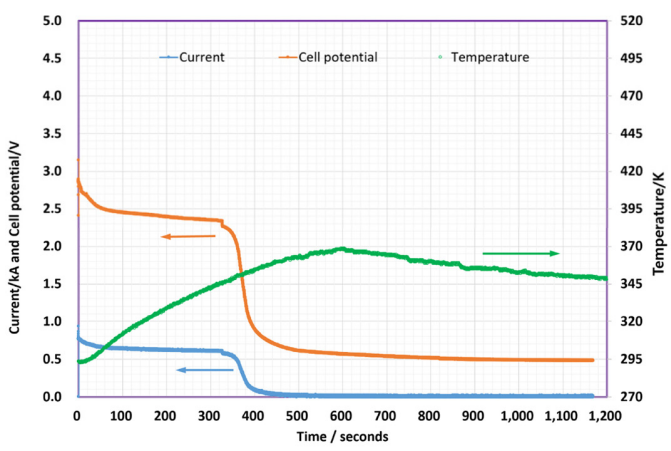

(a)

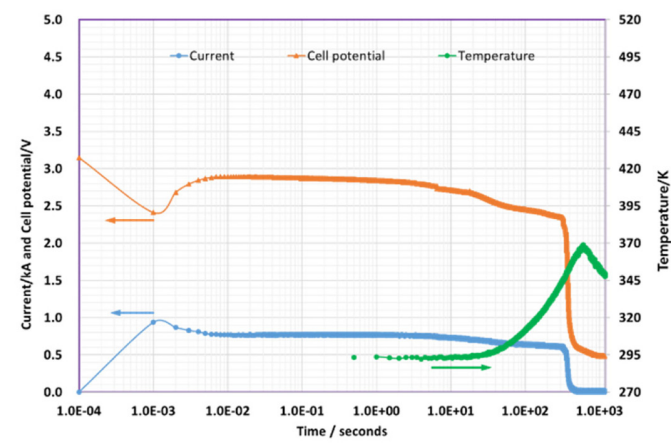

(b)

Fig. 5. Cell potential, current and temperature variations during the resistive discharge with external resistance of $2.91 \mathrm{~m} \Omega$. (a) normal time scale and (b) logarithmic time scale. 
Table 3. Variations of cell potential, current and temperature during resistive discharge with the initial external resistance of $2.91 \mathrm{~m} \Omega$

\begin{tabular}{cccc}
\hline \hline $\begin{array}{c}\text { Time } \\
(\mathrm{sec})\end{array}$ & $\begin{array}{c}\text { Cell potential } \\
(\mathrm{V})\end{array}$ & $\begin{array}{c}\text { Current } \\
(\mathrm{A})\end{array}$ & $\begin{array}{c}\text { Temperature of } \\
\text { center position }(\mathrm{K})\end{array}$ \\
\hline 0 & 4.08 & 0.0026 & 293.55 \\
0.001 & 2.41 & $\mathbf{9 4 0}$ & 292.35 \\
0.006 & 2.88 & 775 & 292.35 \\
0.011 & $\mathbf{2 . 8 9 ( 5 )}$ & 773 & 292.35 \\
60 & 2.49 & 745 & 302.55 \\
330 & 2.34 & 585 & 345.85 \\
400 & 0.89 & 79 & 354.75 \\
495 & 0.614 & 0.0124 & 362.25 \\
541 & 0.587 & - & 365.95 \\
548 & 0.584 & - & 366.05 \\
601 & 0.567 & - & $\mathbf{3 6 8 . 7 5}$ \\
645 & 0.553 & - & 366.75 \\
665 & 0.548 & - & 364.45 \\
\hline
\end{tabular}

*maximum values were marked as bold character

maximum current and the maximum temperature was induced by slow rate of heat diffusion.

\subsection{Resistive discharge with along total external resistance of $2.91 \mathrm{~m} \Omega$}

As a result of resistive discharge with $2.91 \mathrm{~m} \Omega$, which is the sum of the external resistance of $2 \mathrm{~m} \Omega$ and the line resistance of $0.91 \mathrm{~m} \Omega$, the variations in current, voltage and temperature were shown in Fig.
5 and Table 3. The maximum current was $940 \mathrm{~A}$ at 1 mili-seconds as the initially acquired value and decreased with time. The current rapidly decreased to 6 mili-seconds, and then gradually decreased to 60 seconds, and then decreased rapidly. The cell potential increased continuously after a sudden decrease at the initial state and appeared as 2.89(5) V at 11 miliseconds. Thereafter the cell potential was decreased continuously with similar tendency to the current decreasing. The initial increase in cell potential was a result of the decrease in the resistance of the battery electrolyte due to Joule heating of battery. When interpreted as a tendency that the current decreases while the cell potential increases, the overall resistance of the circuit was increased during the initial 6 mili-seconds. Before the resistive discharge, the total external resistance including the electric wire was $2.91 \mathrm{~m} \Omega$. But due to the application of the current according to the resistive discharge, Joule heating was also occurred in the external resistor to increase temperature, and the resistance of the external resistor could be increased due to the rise of temperature.

The temperature of center position $(0.5,0,0.5)$ of battery was increased linearly from the initial temperature of $293.15 \mathrm{~K}$ to $368.75 \mathrm{~K}$ until ca. $600 \mathrm{sec}-$ onds, a maximum temperature was $368.75 \mathrm{~K}$. Although the discharge power according to the resistive discharge was exhausted at around 400 seconds, the maximum temperature was appeared in the range of 560 seconds to show time delay, which was induced by the heat conduction from the inside to the case surface of the battery.

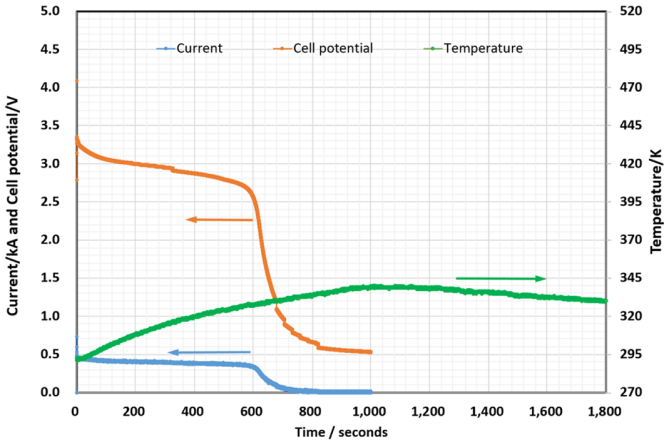

(a)

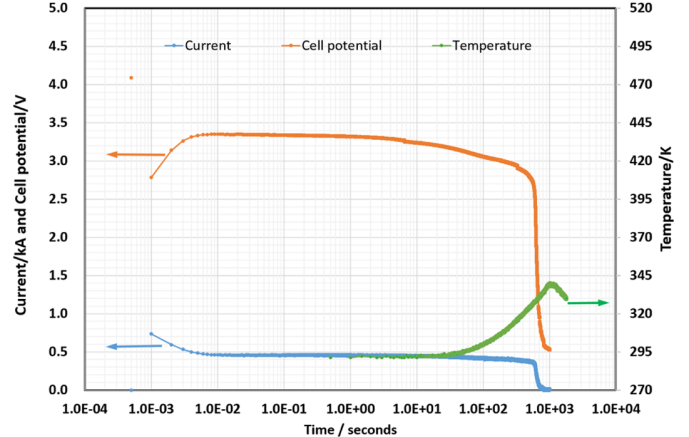

(b)

Fig. 6. Cell potential, current and temperature variations during the resistive discharge with external resistance of $5.91 \mathrm{~m} \Omega$. (a) normal time scale and (b) logarithmic time scale. 


\subsection{Resistive discharge with along total external resistance of $5.91 \mathrm{~m} \Omega$}

The result of the resistive discharge with the total external resistance of $5.91 \mathrm{~m} \Omega$ as the sum of the external resistance of $5 \mathrm{~m} \Omega$ and the wiring resistance of $0.91 \mathrm{~m} \Omega$ was shown at Fig. 6 and Table 4. A trend of the time delay of temperature against current and cell potential was similar to that of the total external resistance of $2.91 \mathrm{~m} \Omega$. At the first measurement at 1 mili-second, a maximum current was recorded as 735 A with cell potential of $2.79 \mathrm{~V}$. The peak cell potential after resistive discharge was $3.35 \mathrm{~V}$ at 9 mili-seconds with the current of $463 \mathrm{~A}$. The plateau region of current and cell potential was endured up to 600 seconds, and then fell down rapidly. Current decay pattern was somewhat similar to constant current. Therefore, the plateau and sudden drop of cell potential could be considered as a pattern of constant current discharge. The highest temperature of center position $(0.5,0,0.5)$ was $340.1 \mathrm{~K}$ at 1,035 seconds.

\subsection{Summary on resistive discharge}

The results according to the total resistance of resistive discharge were summarized as shown in

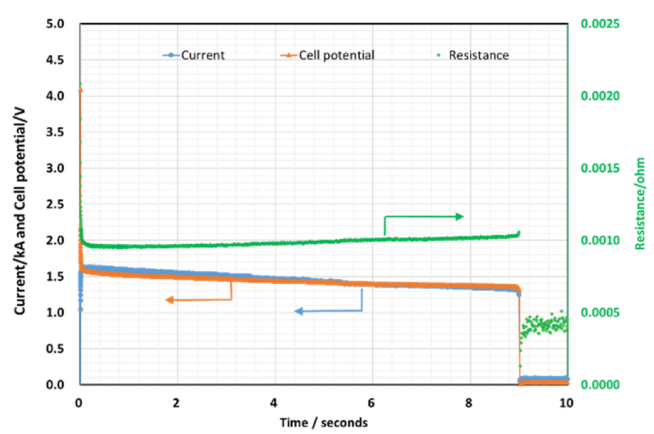

(a)
Fig. 7 and Table 5. The total circuit resistance was appeared to increase linearly against the time progress. The initial time of resistive discharge was set to

Table 4. Variations of cell potential, current and temperature during resistance with the initial external resistance of $5.91 \mathrm{~m} \Omega$

\begin{tabular}{cccc}
\hline \hline $\begin{array}{c}\text { Time } \\
(\mathrm{sec})\end{array}$ & $\begin{array}{c}\text { Cell potential } \\
(\mathrm{V})\end{array}$ & $\begin{array}{c}\text { Current } \\
(\mathrm{A})\end{array}$ & $\begin{array}{c}\text { Temperature of } \\
\text { center position }(\mathrm{K})\end{array}$ \\
\hline 0 & 4.09 & 0 & 292.51 \\
0.001 & 2.79 & $\mathbf{7 3 5}$ & - \\
0.005 & 3.33 & 483 & - \\
0.009 & $\mathbf{3 . 3 5}$ & 463 & - \\
0.5 & 3.33 & 456 & 291.72 \\
1 & 3.32 & 456 & 291.56 \\
615 & 2.34 & 301 & 327.34 \\
860 & 0.57 & 0.003 & 335.70 \\
879 & 0.56 & 0.003 & 335.98 \\
1035 & $\sim 0$ & $\sim 0$ & $\mathbf{3 4 0 . 1 0}$ \\
1049 & $\sim 0$ & $\sim 0$ & 338.55 \\
1056 & $\sim 0$ & $\sim 0$ & 338.71 \\
\hline
\end{tabular}

*maximum values were marked as bold character

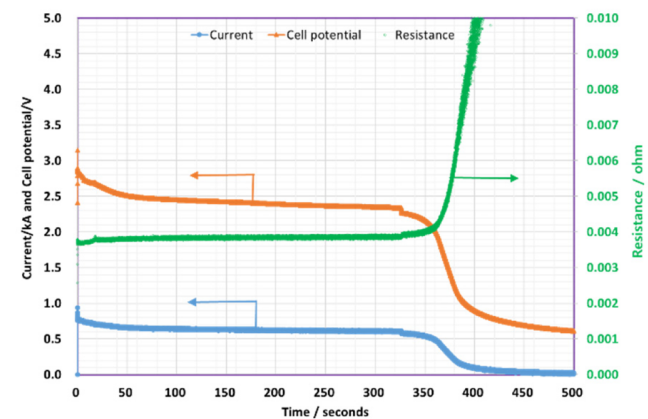

(b)

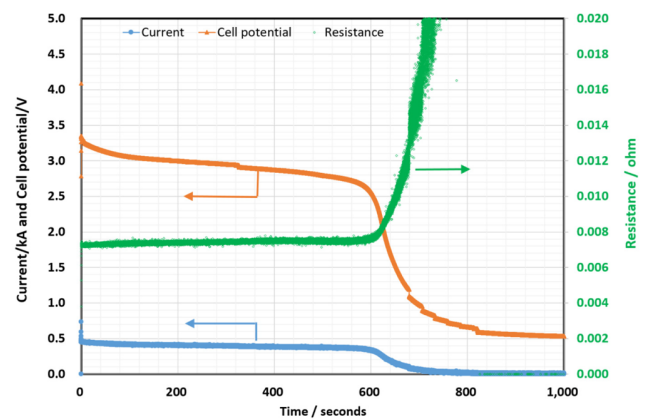

(c)

Fig. 7. Resistance variation during the resistive discharge with external resistance of (a) 0.91 , (b) 2.91 , and (c) $5.91 \mathrm{~m} \Omega$. 
Table 5. Increase of external resistance during resistive discharge

\begin{tabular}{ccccccc}
\hline \hline $\begin{array}{c}\text { Pre-measured external } \\
\text { resistance }(\mathrm{m} \Omega)\end{array}$ & $\begin{array}{c}\text { Resistive discharge } \\
\text { time }(\mathrm{sec})\end{array}$ & $\begin{array}{c}\text { Resistance } \\
(\mathrm{m} \Omega)\end{array}$ & $\begin{array}{c}\text { Resistive discharge } \\
\text { time }(\mathrm{sec})\end{array}$ & $\begin{array}{c}\text { Resistance } \\
(\mathrm{m} \Omega)\end{array}$ & $\begin{array}{c}\text { Resistance } \\
\text { increase }(\%)\end{array}$ \\
\hline 0.91 & 0.8 & 0.949 & $\rightarrow$ & 9 & 1.03 & 8.5 \\
2.91 & 3.34 & 3.649 & $\rightarrow$ & 325 & 3.859 & 5.7 \\
5.91 & 17.18 & 7.067 & $\rightarrow$ & 600 & 7.586 & 7.3 \\
\hline
\end{tabular}

Table 6. Summary of resistive discharge test ${ }^{1)}$

\begin{tabular}{|c|c|c|c|}
\hline \multirow{2}{*}{$\begin{array}{c}\text { Characteristics } \\
\text { Applied total external resistance }(\mathrm{m} \Omega)\end{array}$} & \multicolumn{3}{|c|}{ External resistance } \\
\hline & 0.91 & 2.91 & 5.91 \\
\hline Applied external resistance $(\mathrm{m} \Omega)$ & 0 & 2 & 5 \\
\hline Wiring resistance $(\mathrm{m} \Omega)$ & 0.91 & 0.91 & 0.91 \\
\hline Open-circuit cell potential (V) & 4.09 & 4.09 & 4.09 \\
\hline Cell potential for plateau region $(\mathrm{V})$ & $1.57-$ & $2.50-2.22$ & $3.08-2.63$ \\
\hline Resistive discharge current for plateau region (A) & $1631-$ & $660-552$ & $418-344$ \\
\hline Time of plateau region for cell potential and current (s) & $0.2-?$ & $50-340$ & $80-590$ \\
\hline Initial temperature $(\mathrm{K})$ & 293.15 & 293.15 & 293.15 \\
\hline Final temperature $(\mathrm{K})$ & 310.775 & 368.785 & 340.1 \\
\hline Temperature increase $(\Delta K)$ & 17.625 & 75.635 & 46.95 \\
\hline
\end{tabular}

${ }^{1)}$ the maximum temperature at center position $(0.5,0,0.5$, surface of $\mathrm{x}-\mathrm{Z}$ plane $)$ of battery.

the initial of sudden variation of cell potential with short circuit to external resister. In the case of the external resistance of $0.91 \mathrm{~m} \Omega$, the total resistance of $0.949 \mathrm{~m} \Omega$ at the initial resistive discharge time of 0.8 seconds was increased by $8.5 \%$ to be $1.03 \mathrm{~m} \Omega$ after 9 seconds. In the case of resistive discharge of $2.91 \mathrm{~m} \Omega$ and $5.91 \mathrm{~m} \Omega$, the total resistance increases of $5.7 \%$ and $7.3 \%$, respectively.

The results of resistive discharge with total resistance of $0.91,2.91$, and $5.91 \mathrm{~m} \Omega$ was summarized as Table 6 . The variation of SOC level through the resistive discharge was from 1 of SOC as fully charged to 0 of SOC as fully discharged.

\subsection{Modeling on resistive discharge}

The resistive discharge is a rapid discharge reaction, which is close to an adiabatic state to be a quasiadiabatic state. The battery used in this study was similar one used by Doh et al. [18] in the galvanostatic charge-discharge analysis, and the capacity of battery was somewhat different. Accordingly, the relationship of the variations in the entropy, specific heat capacity, internal resistance, and open circuit cell potential of that report [18] can also be used to the electro-thermo-chemical modeling of the resistive discharge. The relationship between the voltage and the temperature of the battery for the galvanostatic charge-discharge was as Eq. 7 [18]. The electrothermo-chemical modeling for the non-galvanostatic condition to be the resistive discharge could be performed by applying Eq. 8 .

The calculated results of resistive discharge with a total external resistance of $2.91 \mathrm{~m} \Omega$ was presented as Table 7 and Fig. 8. The four cases according to the consideration on the variations of the internal resistance and the entropy of the battery were considered separately to be the results of Figs. 8a-8d. Comparing the maximum temperature of the experimental result of $368.75 \mathrm{~K}$ (Table 3 ), the maximum temperature of resistive discharge modeling by applying the variations of internal resistance of battery with and without entropy changes was $383.6 \mathrm{~K}$ and $380.0 \mathrm{~K}$, respectively. When the internal resistance of the battery was fixed to the initial value, the maximum temperature of resistive discharge modeling was calculated to be $534 \mathrm{~K}$ to $540 \mathrm{~K}$. The resistive discharge had a little 
Table 7. Modeling conditions considering internal resistance and entropy for the external resistance of $2.91 \mathrm{~m} \Omega$

\begin{tabular}{ccccccc}
\hline \hline Modeling condition & Internal resistance & Entropy & $\mathrm{T}_{\text {final }}(\mathrm{K})$ & $\mathrm{I}_{\max }(\mathrm{A})$ & $\mathrm{V}_{\mathrm{CCCP}, \text { ave.plateau }}(\mathrm{V})$ & Remark \\
\hline 1 & $\mathrm{f}(\mathrm{T}, \mathrm{SOC})$ & $\mathrm{f}(\mathrm{SOC})$ & 383.6 & 1020 & 2.78 & Fig. 8a \\
2 & Constant as initial & $\mathrm{f}(\mathrm{SOC})$ & 539.8 & 1099 & 2.77 & Fig. 8b \\
3 & $\mathrm{f}(\mathrm{T}, \mathrm{SOC})$ & 0 & 380.0 & 1019 & 2.76 & Fig. 8c \\
4 & Constant as initial & 0 & 534.0 & 1097 & 2.80 & Fig. 8d \\
\hline
\end{tabular}

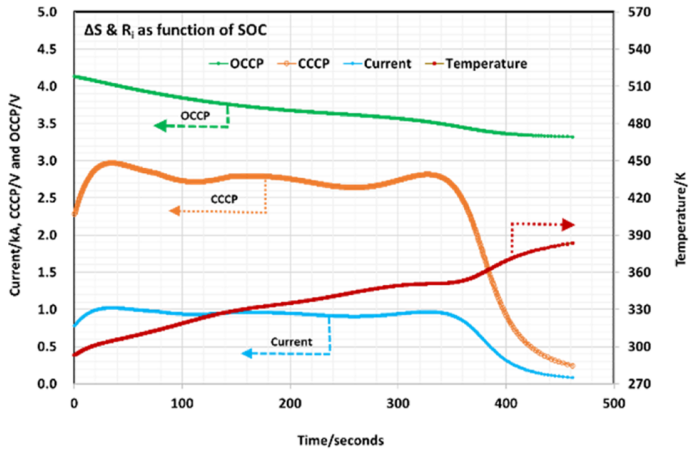

(a)

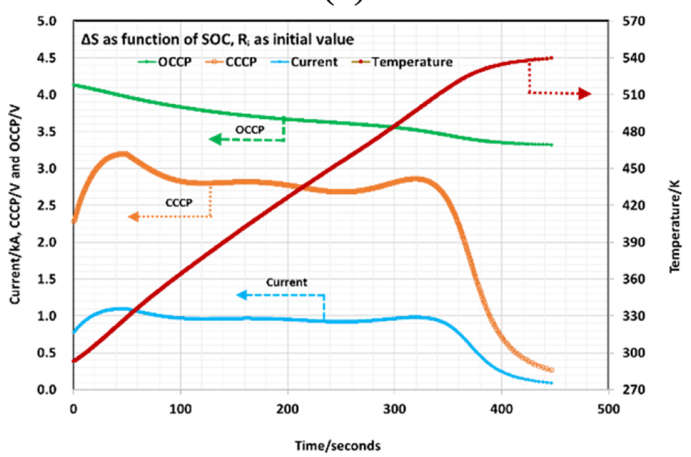

(c)

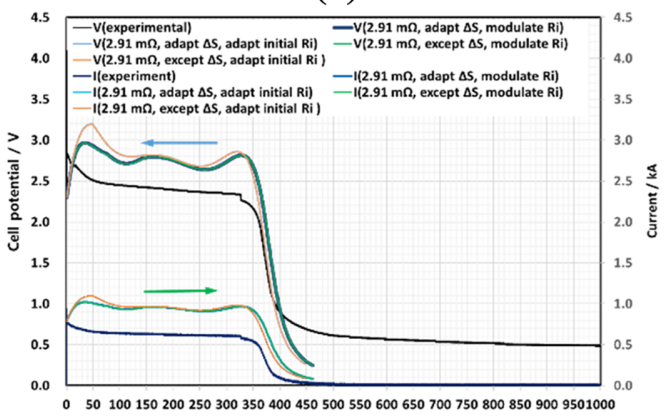

(e)

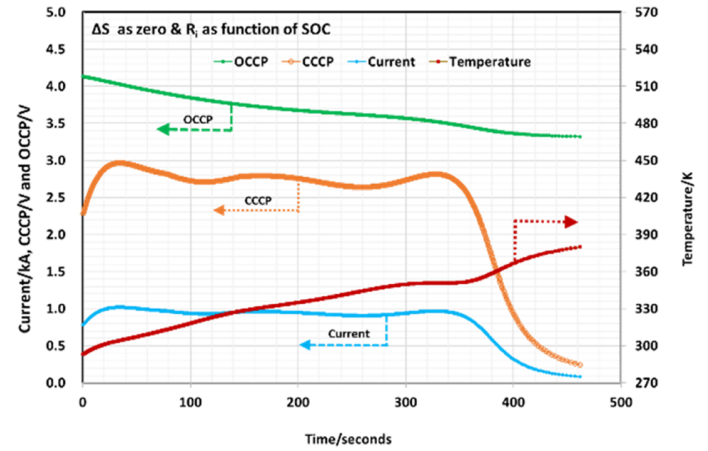

(b)

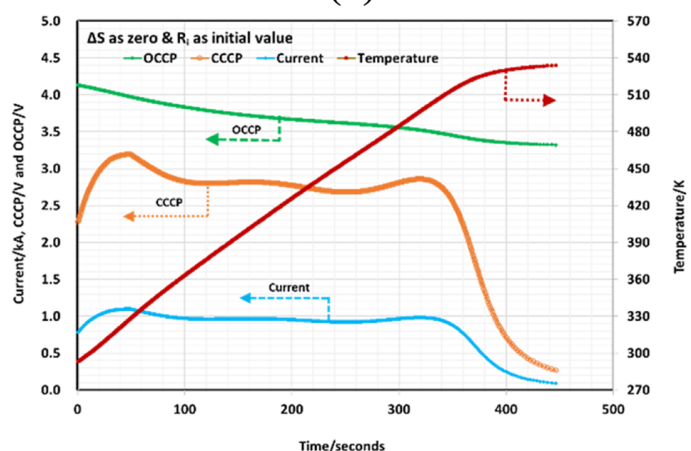

(d)

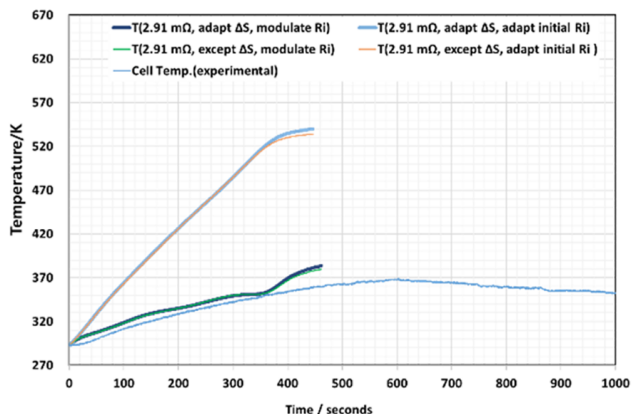

(f)

Fig. 8. Electro-thermo-chemical modeling results for the initial external resistance of $2.91 \mathrm{~m} \Omega$ at the temperature of 293.55 K. (a) considering variations of internal resistance and entropy. (b) considering variations of internal resistance and neglecting entropy variation. (c) fixed internal resistance as initial and considering entropy variation. (d) fixed internal resistance as initial and neglecting entropy variation. (e) cell potential and current of experiment and modeling. (f) cell temperature of experiment and modeling. 


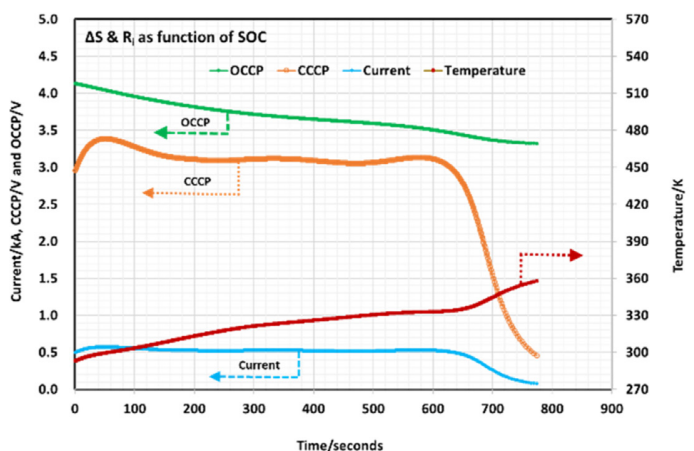

(a)

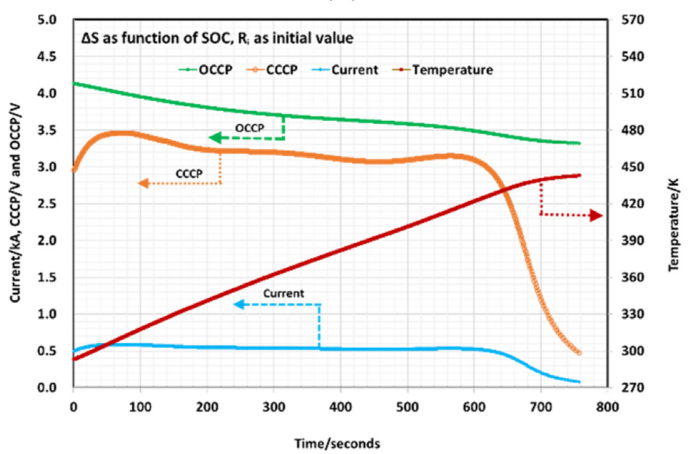

(c)

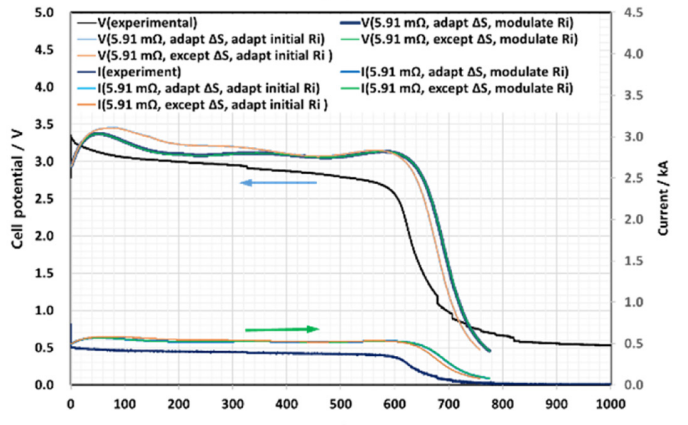

(e)

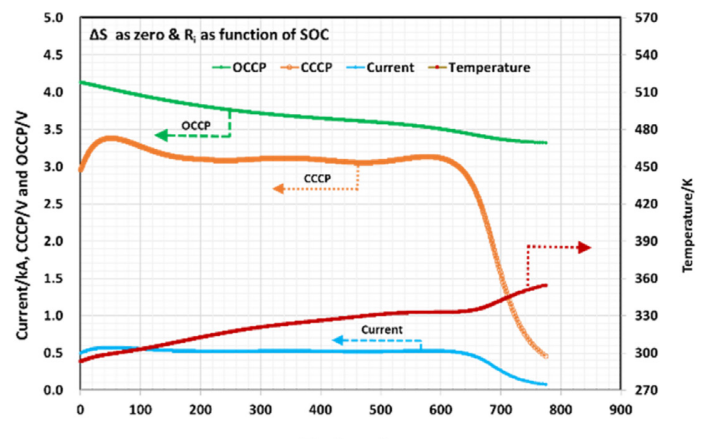

(b)

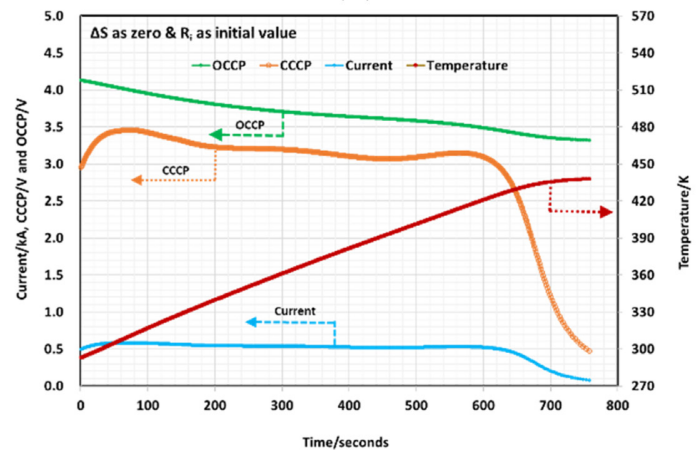

(d)

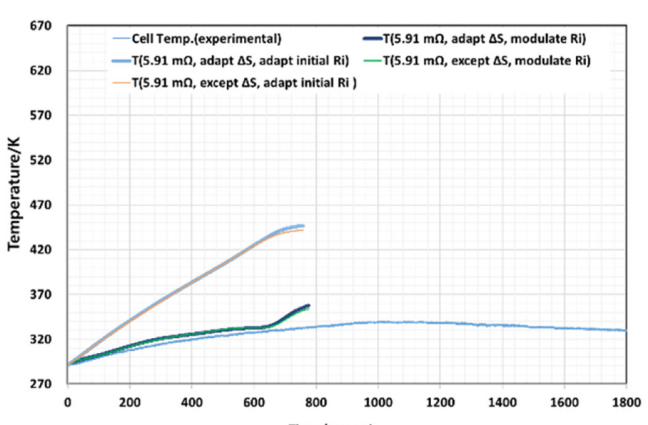

(f)

Fig. 9. Electro-thermo-chemical modeling results for the initial external resistance of $5.91 \mathrm{~m} \Omega$ at the temperature of $291.55 \mathrm{~K}$. (a) considering variations of internal resistance and entropy. (b) considering variations of internal resistance and neglecting entropy variation. (c) fixed internal resistance as initial and considering entropy variation. and (d) fixed internal resistance as initial and neglecting entropy variation. (e) cell potential and current of experiment and modeling. (f) cell temperature of experiment and modeling.

influence on the entropy because a large current flowed, and showed a very large temperature difference depending on whether the variation of internal resistance of battery was considered. In the experimental results, when the cell potential decreased below $1 \mathrm{~V}$, it took about 390 seconds, and in modeling, it was 398 seconds to be a good correspondence.
The modeling results of the resistive discharge with a total external resistance to $5.91 \mathrm{~m} \Omega$ was shown at Table 8 and Fig. 9. Comparing the maximum temperature of the experimental result of $340.1 \mathrm{~K}$ (Table 4 ), the maximum temperature of resistive discharge modeling by applying the variations of internal resistance of battery with and without entropy changes was $357.7 \mathrm{~K}$ and 
Table 8. Modeling conditions considering internal resistance and entropy for the external resistance of $5.91 \mathrm{~m} \Omega$

\begin{tabular}{ccccccc}
\hline \hline Modeling condition & Internal resistance & Entropy & $\mathrm{T}_{\text {final }}(\mathrm{K})$ & $\mathrm{I}_{\max }(\mathrm{A})$ & $\mathrm{V}_{\text {CCCP,ave.plateau }}(\mathrm{V})$ & Remark \\
\hline 1 & $\mathrm{f}(\mathrm{T}, \mathrm{SOC})$ & $\mathrm{f}(\mathrm{SOC})$ & 357.9 & 373 & 3.11 & Fig. 9a \\
2 & Constant as initial & $\mathrm{f}(\mathrm{SOC})$ & 443.0 & 586 & 3.17 & Fig. 9b \\
3 & $\mathrm{f}(\mathrm{T}, \mathrm{SOC})$ & 0 & 354.5 & 572 & 3.11 & Fig. 9c \\
4 & Constant as initial & 0 & 438.0 & 585 & 3.17 & Fig. 9d \\
\hline
\end{tabular}

354.5 K, respectively. When the internal resistance of the battery was fixed to the initial value, the maximum temperature of resistive discharge modeling was calculated to be about $438.0 \mathrm{~K} \sim 443.0 \mathrm{~K}$. In the experimental results, when the voltage decreased to $1 \mathrm{~V}$, it took about 700 seconds, and in modeling, it was 640 seconds.

In the fixed case of the internal resistance as the initial value in the electro-thermo-chemical modeling for the above two external resistances, it was found that it is very important to consider the change in the internal resistance by showing a large difference from the experimental results.

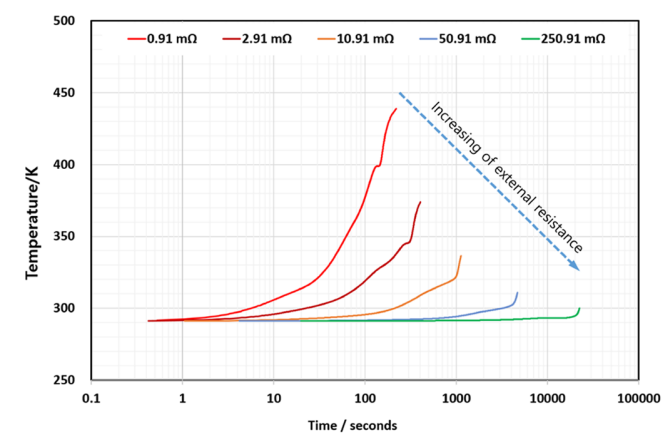

(a)

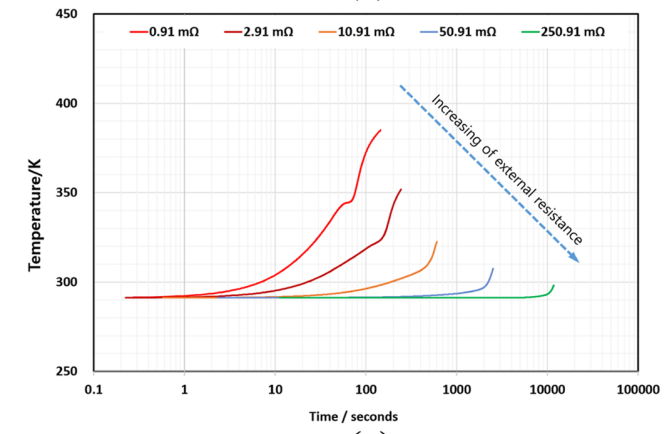

(c)
Contributions with or without the application of an entropy changes was a little under the conditions of this resistive discharge. A reason is that in the resistive discharge environment, the contribution of heat generation via Joule heating is significantly increased, and the heat contribution of the entropy is relatively low. Therefore, it is considered that the contribution of the entropy is negligible in the electro-thermo-chemical model calculation for the rapid discharge environment such as the resistive discharge. Variations in current and cell potential were appeared delicate in modeling, but slowly in experiments. In the case of the experiment, the cell potential and the current has

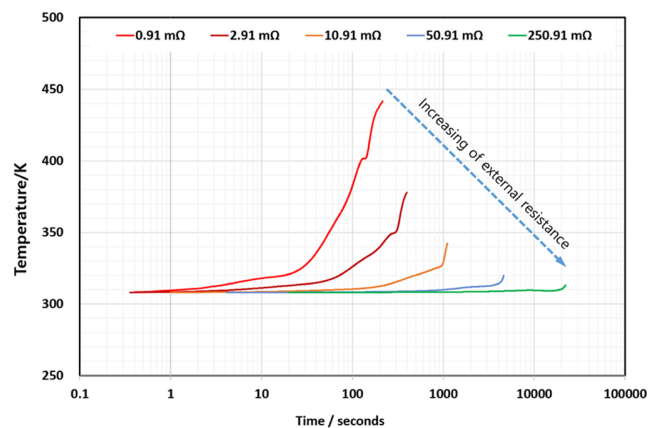

(b)

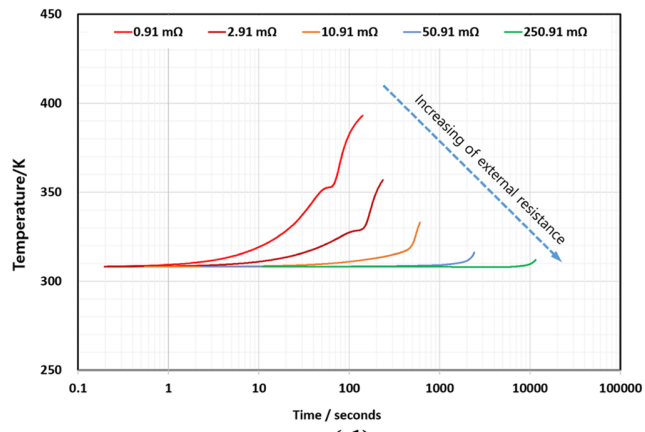

(d)

Fig. 10. Calculated temperature variations during the resistive discharge of batteries through electro-thermo-chemical modeling. (a) SOC $(1 \rightarrow 0), 291.15 \mathrm{~K}$, (b) SOC $(1 \rightarrow 0), 308.15 \mathrm{~K}$, (c) SOC $(0.5 \rightarrow 0), 308.15 \mathrm{~K}$, and (d) SOC $(0.5 \rightarrow 0)$, $291.15 \mathrm{~K}$. 

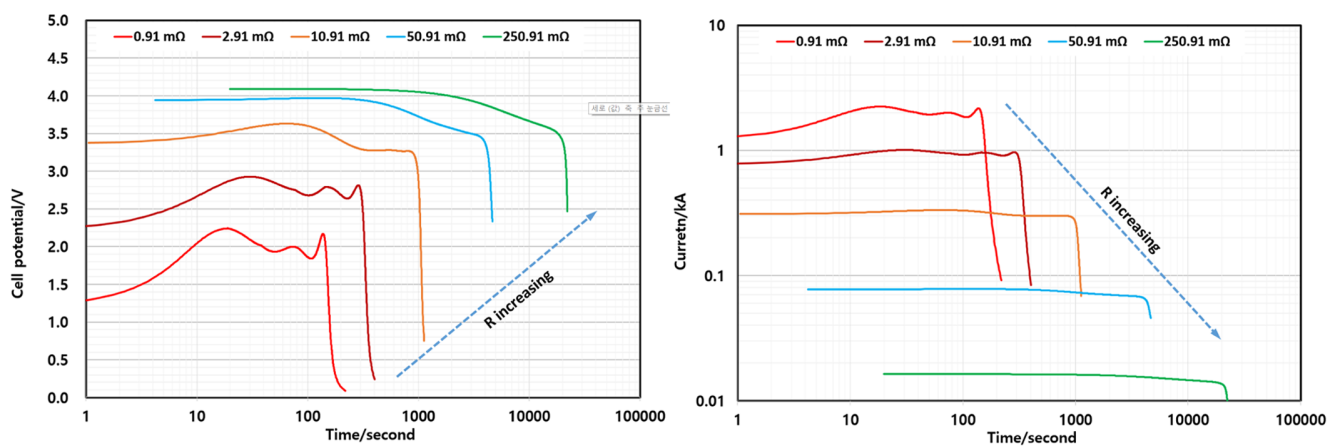

(a)
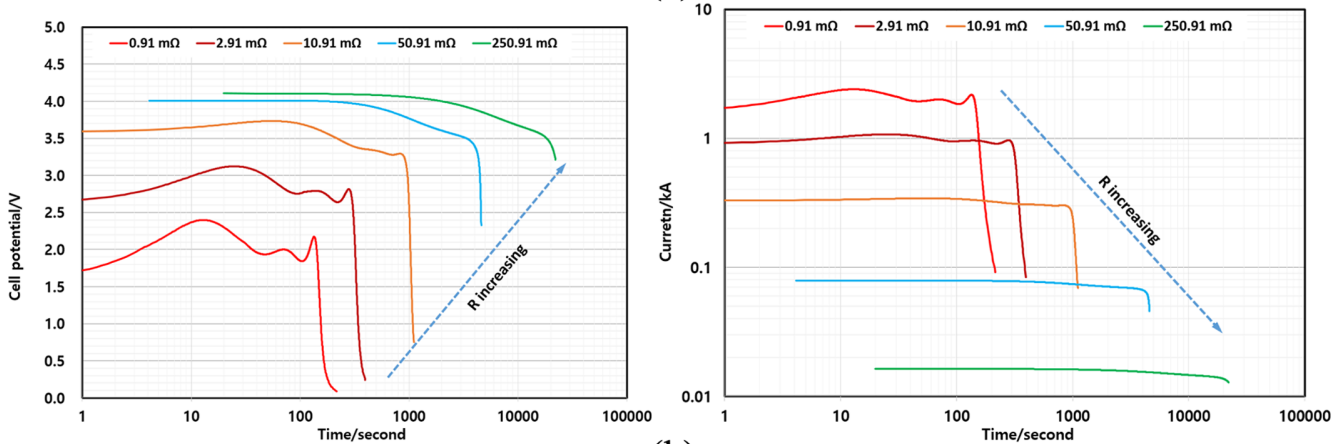

(b)
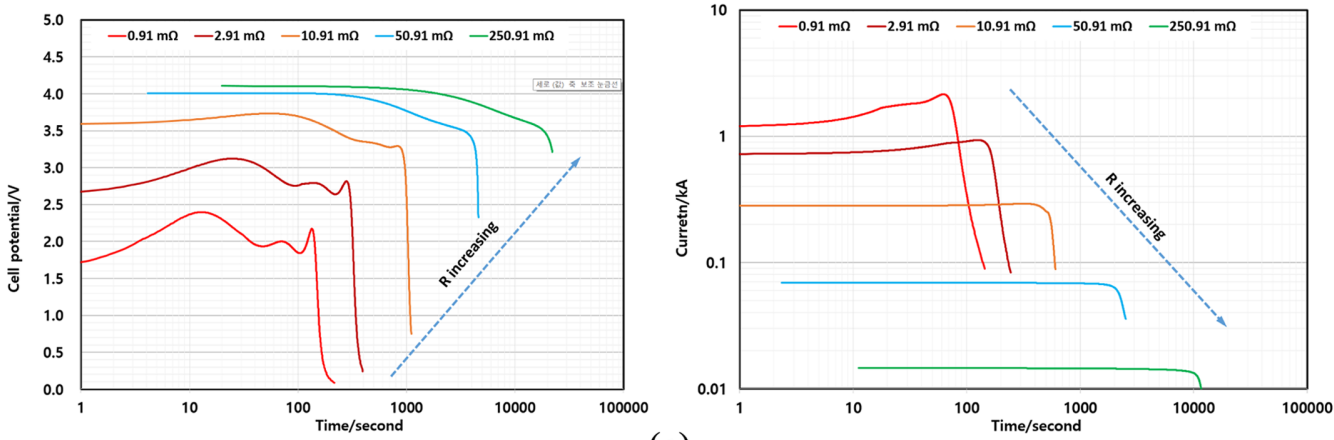

(c)
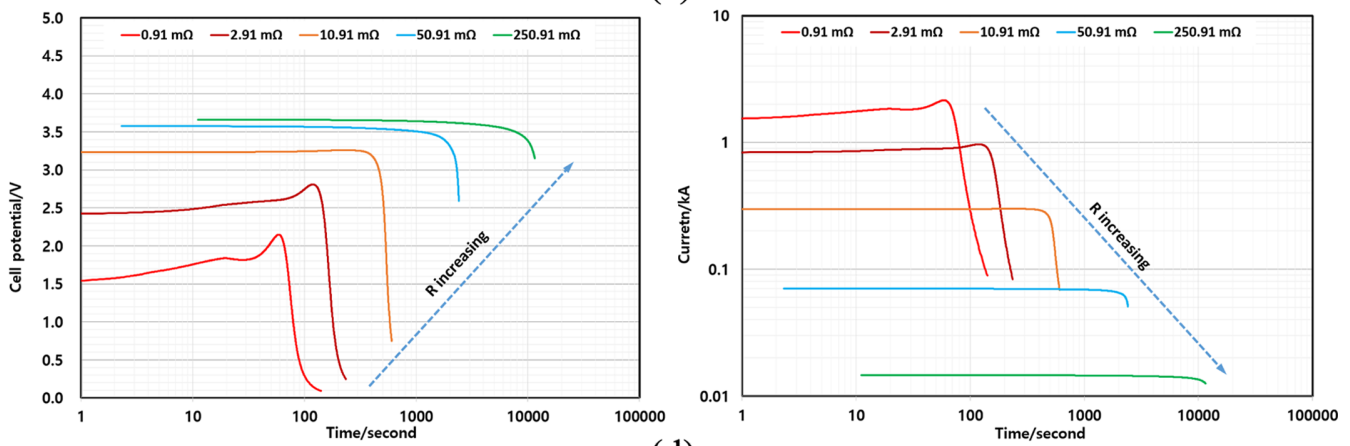

(d)

Fig. 11. Calculated cell potential and current variations during the resistive discharge of batteries through electro-thermochemical modeling. (a) SOC $(1 \rightarrow 0), 291.15 \mathrm{~K}$, (a1) cell potential, (a2) current; (b) SOC $(1 \rightarrow 0), 308.15 \mathrm{~K}$, (b1) cell potential, (b2) current; (c) SOC $(0.5 \rightarrow 0), 308.15 \mathrm{~K}$, (c1) cell potential, (c2) current; (d) SOC $(0.5 \rightarrow 0), 291.15 \mathrm{~K}$, and (d1) cell potential, (d2) current. 
trode, and accordingly, the average results of the cell potential and the current were measured to be shown as a smooth result. As described above, when considering the change of entropy, internal resistance, and open circuit potential according to the change of SOC, the temperature variation of modeling was better matched with the experimental result. Results of the resistive discharge with an external resistance of 2.91 and $5.91 \mathrm{~m} \Omega$ were plotted as Fig. 8(e,f) and Fig. $9(\mathrm{e}, \mathrm{f})$ with experiment and modeling together. Cell potential and current of modeling had swaying pattern by the adoption of an assumption of that all electrochemically active material will take the reaction concurrently. Anyways at real battery reaction, every electrochemically active material has different electrochemical environments to be appeared their own chemical potential. Therefore, cell potential and current of experiment would be measured as an average value to be flatly changed. Discrepancy on average cell potential and current might be caused by errors of data measuring equipment and modeling method together. Modeling was carried out with/without

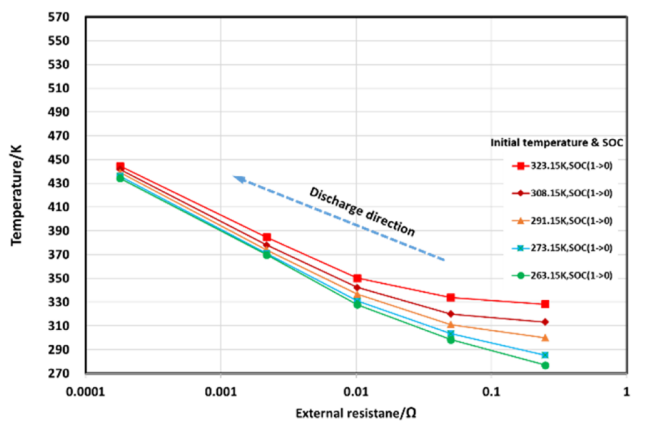

(a)

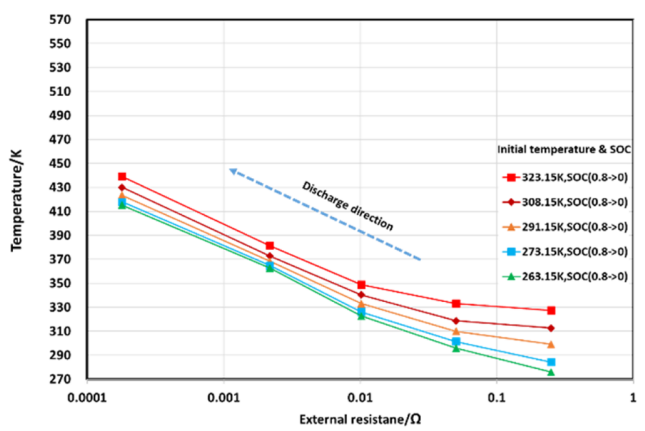

(c) adoption of entropy term and variable internal resistance term to be 4 cases. Cell potential and current changing pattern were not so seriously varied, but cell temperature was far differently changed with/ without the variation of internal resistance. Modeling with the modulation of cell internal resistance as a function of SOC and cell temperature had good correspondence to experimental result.

\subsection{Extension of Electro-Thermo-chemical model- ing to unknown resistive discharge conditions}

This electro-thermo-chemical modeling could be applied to predict the resistive discharge of unknown conditions. Substantial resistive discharge could be occurred at various charge states and temperatures. As an example of a typical resistive discharge, we would like to show the modeling result of resistive discharge from SOC $100 \%$ and $50 \%$ to SOC $0 \%$. A battery of SOC $100 \%$ was charged to cell potential of $4.15 \mathrm{~V}$ to have the capacity of $90 \mathrm{Ah}$. The resistance of resistive discharge was modeled by applying $0 \mathrm{~m} \Omega, 2 \mathrm{~m} \Omega, 10 \mathrm{~m} \Omega, 50 \mathrm{~m} \Omega$, and $250 \mathrm{~m} \Omega$ with a

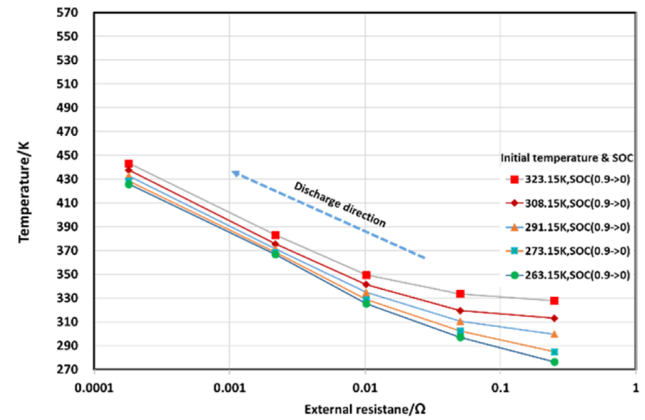

(b)

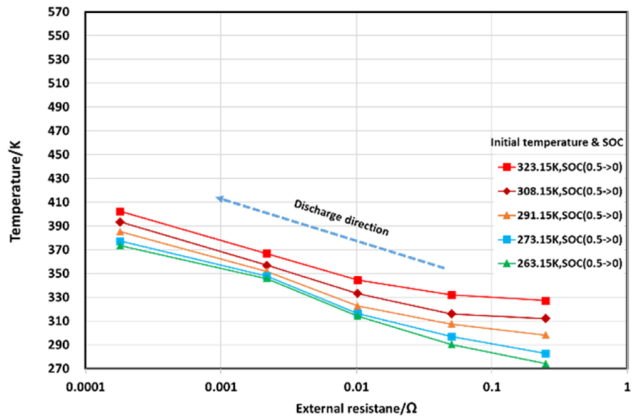

(d)

Fig. 12. Calculated temperature variations during the resistive discharge of batteries through electro-thermo-chemical modeling. (a) SOC $(1 \rightarrow 0)$, (b) SOC $(0.9 \rightarrow 0)$, (c) SOC $(0.8 \rightarrow 0)$, and (d) SOC $(0.5 \rightarrow 0)$. 
Table 9. Modeling conditions considering internal resistance and entropy

\begin{tabular}{|c|c|c|c|c|c|c|c|c|c|c|c|c|c|c|c|c|}
\hline \multicolumn{2}{|c|}{$\begin{array}{c}\text { Initial } \\
\text { condition }\end{array}$} & \multicolumn{3}{|c|}{$\mathrm{R}_{\text {external }}: 0.91 \mathrm{~m} \Omega$} & \multicolumn{3}{|c|}{$\mathrm{R}_{\text {external }}: 2.91 \mathrm{~m} \Omega$} & \multicolumn{3}{|c|}{$\mathrm{R}_{\text {external }}: 10.91 \mathrm{~m} \Omega$} & \multicolumn{3}{|c|}{$\mathrm{R}_{\text {external }}: 50.91 \mathrm{~m} \Omega$} & \multicolumn{3}{|c|}{$\mathrm{R}_{\text {external }}: 250.91 \mathrm{~m} \Omega$} \\
\hline $\begin{array}{c}\text { SOC } \\
\text { (initial } \\
\text { /final) }\end{array}$ & $\begin{array}{l}T_{\text {initial }} \\
(\mathrm{K})\end{array}$ & $\begin{array}{l}\mathrm{I}_{\max } \\
\text { (A) }\end{array}$ & $\begin{array}{l}\mathrm{T}_{\max } \\
(\mathrm{K})\end{array}$ & $\begin{array}{l}\mathrm{t}_{\text {end }} \\
(\mathrm{s})\end{array}$ & $\begin{array}{l}\mathrm{I}_{\max } \\
\text { (A) }\end{array}$ & $\begin{array}{l}T_{\max } \\
(\mathrm{K})\end{array}$ & $\begin{array}{l}t_{\text {end }} \\
(\mathrm{s})\end{array}$ & $\begin{array}{l}\mathrm{I}_{\max } \\
\text { (A) }\end{array}$ & $\begin{array}{l}\mathrm{T}_{\max } \\
(\mathrm{K})\end{array}$ & $\begin{array}{l}\mathrm{t}_{\text {end }} \\
\text { (s) }\end{array}$ & $\begin{array}{l}\mathrm{I}_{\max } \\
\text { (A) }\end{array}$ & $\begin{array}{l}\mathrm{T}_{\max } \\
(\mathrm{K})\end{array}$ & $\begin{array}{l}t_{\text {end }} \\
\text { (s) }\end{array}$ & $\begin{array}{l}\mathrm{I}_{\max } \\
\text { (A) }\end{array}$ & $\begin{array}{l}\mathrm{T}_{\max } \\
(\mathrm{K})\end{array}$ & $\begin{array}{l}\mathrm{t}_{\text {end }} \\
\text { (s) }\end{array}$ \\
\hline $1 / 0$ & 291 & 2,241 & 439 & 219 & 1,006 & 374 & 403 & 333 & 337 & 1,126 & 78 & 311 & 4,576 & 16 & 300 & 22,315 \\
\hline $1 / 0$ & 308 & 2,398 & 442 & 215 & 1,073 & 378 & 396 & 342 & 342 & 1,107 & 79 & 320 & 4,601 & 16 & 313 & 22,125 \\
\hline $0.5 / 0$ & 291 & 2,143 & 385 & 144 & 932 & 352 & 243 & 292 & 323 & 603 & 69 & 307 & 2,515 & 15 & 298 & 11,732 \\
\hline $0.5 / 0$ & 308 & 2,148 & 393 & 140 & 965 & 357 & 235 & 299 & 333 & 604 & 70 & 316 & 2,409 & 15 & 312 & 11,562 \\
\hline
\end{tabular}

wiring resistance of $0.91 \mathrm{~m} \Omega$. The calculated results of the variations in temperature, cell potential and current for the initial temperature of $291.15 \mathrm{~K}$ and 308.15 K were presented as Fig. 10 and Fig. 11. The maximum current, the maximum temperature, and resistive discharge time for 20 different conditions by 4 initial conditions and 5 different external resistances were summarized at Table 9 . When a battery was resistively discharged from the initial SOC of $100 \%$ to the initial SOC of $0 \%$ with the external resistance of $0.91 \mathrm{~m} \Omega$ and the initial temperature of $291.15 \mathrm{~K}$, the maximum current and the maximum temperature were calculated as 2,241 A and $439.15 \mathrm{~K}$, and the time durations was calculated as 219 seconds. For the resistive discharge with conditions of the initial temperature of $263.15 \mathrm{~K}, 273.15 \mathrm{~K}, 291.15 \mathrm{~K}$, $308.15 \mathrm{~K}$ and $323.15 \mathrm{~K}$, the initial SOC of $1,0.9,0.8$, and 0.5 , and the external resistance of $0.91 \mathrm{~m} \Omega$, $2.91 \mathrm{~m} \Omega, 10.91 \mathrm{~m} \Omega, 50.91 \mathrm{~m} \Omega$, and $250.91 \mathrm{~m} \Omega$, the maximum temperature to be the final temperature was drawn as Fig. 12 to show a linear relationship with the log-scale of external resistance. In this way, the application of the electro-thermo-chemical modeling could applied to predict the behaviors of the cell potential, current, and temperature over time of the resistive discharge for various conditions.

\section{Conclusions}

The properties of the resistive discharge of a lithium ion battery with a capacity of $90 \mathrm{Ah}$ were evaluated. For the electro-thermo-chemical modeling of resistive discharge, the relationship of the variation in cell potential, current and temperature were correlated as function of SOC. An iterative calculation program was developed to solve the electro-thermochemical modeling of resistive discharge based on
SOC. The iteratively calculated results were compared to the experimental results to have a good correspondence. For the unknown resistive discharge condition, this electro-thermo-chemical modeling could be applied to predict the variation of cell potential, current and temperature.

\section{Acknowledgments}

This research was partly supported by the Korea Electrotechnology Research Institute (KERI) Primary research program (No. 21A01012) through the National Research Council of Science and Technology (NST) funded by the Ministry of Science and ICT (MSIT, Korea) and by the Korea Institute of Energy Technology Evaluation and Planning (KETEP) grant funded by the Ministry of Trade, Industry \& Energy (MOTIE, Korea) (No. 20206910100090).

\section{References}

[1] D. Ouyang, M. Chen, Q. Huang, J. Weng, Z. Wang, J. Wang, Appl. Sci., 2019, 9(12), 2483.

[2] X. Feng, M. Ouyanga, X. Liua, L. Lua, Y. Xia, X. He, Energy Storage Mater, 2018, 10, 246-267.

[3] D. Bernardi, E. Pawlikowski, J Newman, J. Electrochem. Soc., 1985, 132(1), 5-12.

[4] C. H. Doh, D. H. Kim, J. H. Lee, D. J. Lee, B. S. Jin, H. S. Kim, S. I. Moon, Y. K. Hwang, Veluchamy, Bull. Korean Chem. Soc., 2009, 30(4), 783-786.

[5] U. S. Kim, C. B. Shin, C. S. Kim, J. Power Sources, 2008, 180(2), 909-916.

[6] J. S. Yi, U. S. Kim, C. B. Shin, T. Y. Han, S. Y. Park, J. Electrochem. Soc., 2013, 160(3), A437.

[7] I. Uchida, H. Ishikawa, M. Mohamedi, M. Umeda, J. Power Sources, 2003, 119, 821-825.

[8] A. Abaza, S. Ferrari, H. K. Wong, C. Lyness, A. Moore, J. Weaving, M. Blanco-Martin, R. Dashwoodd, R. Bhagat, J. Energy Storage, 2018, 16, 211-217.

[9] N. Ganesan, S. Basu, K. S. Hariharan, S. M. Kolake, T. 
Song, T. Yeo, S. Doo, J. Power Sources, 2006, 322, 5767.

[10] D. H. Jeon, S. M. Baek, Energy Convers. Manag., 2011, 52(8-9), 2973-2981.

[11] Z. Chen, R. Xiong, J. Lu, X. Li, Appl. Energy, 2018, 213, 375-383.

[12] A. Kriston, A. Pfrang, H. Doring, B. Fritsch, V. Ruiz, I. Adanouj, T. Kosmidou, J. Ungeheuer, L. Boon-Brett, $J$. Power Sources, 2017, 361, 170-181.

[13] A. Rheinfeld, A. Noel, J. Wilhelm, A. Kriston, A.
Pfrang, A. Jossen, J. Electrochem. Soc., 2018, 165(14), A3427.

[14] A. Rheinfeld, J. Sturm, A. Frank, S. Kosch, S. V. Erhard, A. Jossen, J. Electrochem. Soc., 2020, 167(1), 013511

[15] K. E. Thomas, J. Newman, J. Power Sources, 2003, 119, 844-849.

[16] C. H. Doh, Y. C. Ha, S. W. Eom, Electrochim. Acta, 2019, 309, 382-391. 